\title{
The Profile of Vocational High School Students Literacy Skill As a Case Study in Electronics Workbench (EWB) Learning Media Implementation in Semarang City
}

\author{
Riskana Br Sitepu ${ }^{1}$, Ani Rusilowati ${ }^{2}$, Bambang Subali ${ }^{3}$, Ahmad Sukron Khafifi ${ }^{4}$, Muntammah ${ }^{5}$ \\ \{riskanasitepu17@gmail.com., Rusilowati@mail.unnes.ac.id², \\ bambangfisika@mail.unnes.ac.id ${ }^{3}$, sayasoekron@yahoo.com ${ }^{4}$, \\ muntamahamri78@gmail.com $\left.{ }^{5}\right\}$ \\ Universitas Negeri Semarang ${ }^{1,2,3,4}$ \\ SMK Negeri 1 Semarang ${ }^{5}$
}

\begin{abstract}
The purpose of this study is to analyze the IT literacy skills of Vocational students in the implementation of Electronics Workbench (EWB) learning media in Semarang City. This study uses a quantitative descriptive method with a survey method. This research was conducted in four Vocational High Schools in Semarang City with high and low categories. The subject of this study is determined by purposive sampling technique. Measuring instruments in this study uses test essay questions, questionnaires and interviews. The results of the analysis shows that the students' literacy capabilities based on 5 test results. They are understanding how to access internet information obtained (91.2\%), understanding how to use the computer, understanding how to print work results and identifying internet information (83.4\%) and presenting the results that have been worked out (75\%). From the results of questionnaires and interviews, it can be concluded that EWB media greatly helped teachers and students to advance their IT literacy skills.
\end{abstract}

Keywords: Electronics Workbench (EWB), IT literacy, Vocational High School Students

\section{Introduction}

Education is a necessity which must be acquired for all Indonesian citizens who aim to improve their quality of human resources. Current education should no longer teach about learning that directs students to merely memorize, but also to be able to integrate the ability to reason in their activities [1]. In the 21 st century, the teaching and learning process must go beyond content knowledge towards a holistic attitude and mastery of technology [2]. By applying 21 st century learning, students are able to learn independently and in groups so that later students are ready to face the world of work [3]. Skills which must be prepared for 21st century students including skills in cooperation, communication, creativity, critical thinking; applying information technology, problem-solving and self-regulating skills [4]. However, in 
fact there are still many weaknesses in the learning process both from the teacher and from the students themselves. Some studies reveal that students' learning difficulties are still found including difficulties in mastering concepts, linking the relationship between concepts, mastering formulas and operating formulas when solving problems [5]. Based on the results of interviews conducted by $10^{\text {th }}$ grade physics teachers in four public and private vocational schools in the city of Semarang in September 2018, it was found that the students have lack of attractiveness in responding to the learning of Physics taught by the teachers since their teachers still teach the course conventionally and rarely use learning media in the learning and teaching process.

The research result at Wonosobo Vocational School can be concluded that students' conceptual understanding is still low. This happens because students do not understand the physics concepts taught by the teacher. In addition, conventional learning also makes a lack of motivation for students to find information about physics on the internet. This habit then has an impact on students' low understanding of concepts and IT literacy [6]. From the problems that have been brought above, it is necessary to implement a media that puts to the attractiveness of students. EWB learning media is one of the solutions to make students being more interested in learning physics. EWB is a computer software that can be used to simulate the workings of an analogue and digital electronic platforms. The advantages of this application are helping students in analysing a series that cannot be measured directly at the lab. By implementing this media, it is expected that students' IT literacy skills will increase. Some parents in Uganda have trained their children to literate their literacies by applying an exercise in the form of a digital project [7].

The purpose of this study is to analyse the profile of students' IT literacy skills after the implementation of EWB learning media has been conducted in the Semarang City Vocational Schools.

\section{Method}

This research is a quantitative descriptive study with a survey method. This research is conducted in four Vocational Schools in Semarang City with high and low categories. The subject of this study is determined by purposive sampling technique. From there, the researcher chooses the schools in Negeri Jateng and Texmacho Vocational Schools with high category. Meanwhile State Vocational High School 1 and 17 Agustus Private Vocational School, 1945 are in low category. The purpose of selecting the category is to see whether EWB learning media is capable of being implemented in each school category. There are 114 student samples from 4 schools in total. They are 25 students from Negeri Jateng, 31 students from State Vocational High School 1, 33 students from Texmacho Private Vocational Schools, 25 students from 17 Agustus Private Vocational High School. The learning instruments used consist of teaching materials, syllabus and Learning Implementation Plans (LIP) that refer to the implementation of EWB learning media to improve student IT literacy, worksheets and also EWB media tutorials.

The research instruments used are IT literacy ability, questionnaires and interviews. The first instrument consists of five aspects; 1) understanding how to use the computer, 2) being able to of printing out work results, 3) presenting the results that have been worked out, 4) identifying internet information, 4) understanding how to use internet information. The result research data are analysed by quantitative descriptive statistic [8]. EWB media learning is 
arranged in learning implementation plans (LIP) since it is still found low literacy aspect implemented [9]. This plan then is collaborated with Problem Solving learning. This model is chosen because it is strongly connected each other as the problems appearing on EWB media learning process need to be accomplished. By applying this model, it can be directed to start asking and finding the solutions, doing reflexing, building data knowledge, collaborating and also sharing information, growing concept and the relation based on observation and experiment [10]. Science teachers ask their students to learn two things. They are various types of scientific research and also actively learning through that research. They encourage their students in individual or in group to observe, submit questions or problems, design an experiment, and also to submit and interpret the data. Those ways motivate the students to build and relate between concepts and observations.

\section{Results and Discussion}

\subsection{The Profile of Students' IT Literacy Capabilities Based on Test}

The profile of students' IT literacy capabilities based on five aspects for each school category which are shown in the table below.

Table 1. Result of IT Literacy Capability's Students

\begin{tabular}{lcccccc}
\hline \multirow{2}{*}{ IT Literacy Aspects } & State & \multicolumn{3}{c}{ Private } & \% \\
\cline { 2 - 5 } & High & Low & High & Low & \\
\hline $\begin{array}{l}\text { Understanding how to } \\
\text { use the computer }\end{array}$ & 3 & 3 & 3 & 2 & 83.4 \\
$\begin{array}{l}\text { Being able to of } \\
\text { printing out work }\end{array}$ & 3 & 2 & 2 & 3 & 83.4 \\
$\begin{array}{l}\text { results } \\
\text { presenting the results } \\
\text { which have been }\end{array}$ & 2 & 2 & 2 & 3 & 75 \\
$\begin{array}{l}\text { worked out } \\
\text { Identifying internet } \\
\text { information }\end{array}$ & 2 & 2 & 3 & 2 & 83.4 \\
$\begin{array}{l}\text { Understanding how to } \\
\text { access internet } \\
\text { information }\end{array}$ & 3 & 3 & 2 & 3 & 91.2 \\
\hline
\end{tabular}

From the table above, it is shown that there are some level differences of students' IT literacy capabilities for each school category. This can be seen from State Vocational Schools that the students' capabilities are higher in high school category (Negeri Jatneg Vocational School) with average score 82.04. For private schools' literacy abilities are in low school category (17 Agustus 1945) with average score 86.40. Nevertheless, for all literacy capabilities aspects are in very good category. This can be concluded that it happens because it has strong connection with the implementation of EWB learning media. 


\subsection{The Profile of Students' IT Literacy Capabilities Based on Questionnaires}

Table 2. Result of Teacher and Student's Questionnaires

\begin{tabular}{cc}
\hline Respondents & EWB Learning Media (\%) \\
\hline Teachers & 79.91 \\
Students & 80.26 \\
\hline
\end{tabular}

Based on the table 2 above, it can be stated that the responds from both teachers and students about the implementation of EWB learning media gains positive responses with percentage obtained are $79.91 \%$ and $80.26 \%$. This means that it is listed in high category. Both of teachers and students are getting more acknowledgeable to understand the materials using EWB which is quite easy to use. It also can attract the students in learning more about physics materials especially about electricity. From the teachers' side, they believe that it's not only to ease the way they teach but also to help them learn IT literacy. This is highly connected each other with learning process demand in 21 st century that the teachers should be able to provide new information into the newest technology. Thus, the materials thought are actual and contextual for the students. The teachers nowadays also should be more critical and more literate in order it can help them and their students become familiar with the internet.

\subsection{The Profile of Students' IT Literacy Capabilities Based on Interviews}

The interview results gained from four vocational schools shows that the implementation of EWB learning media gives positive impacts sine they had never been conducted this model previously. This easy application attracts them to use alone themselves if they have computer. Thus, they can practice and improve their creativity skill at home instead.

\section{Conclusion}

Profile of IT literacy capabilities of Vocational students in Semarang City is in very good category overall after implementing EWB media learning. Those capabilities based on five aspects; understanding how to access internet information (91.2\%), know how to use computer, print out the work result, understand how to identify internet information (83.4\%), and also understand how to present the work result (75\%). From the results of questionnaires and interviews, it shows that using EWB media is greatly helpful for both teachers and students to improve their IT literacy capabilities. From the analysis result, it can be summarised that the profile of IT literacy capabilities of vocational students using EWB learning media implementation in Semarang City is in very good category. Thus, the researcher hopes that the teachers can implement this media and learning model to create students' activeness. 


\section{References}

[1] Oktafianti, E. Implementasi of scientific approach based larning in 1 st B grader of Pujokusuman 1 Yogyakarta. Jurnal Pendidikan Sekolah Dasar, 9 (IV). (2015)

[2] Lee, S.S., Hung, D., \& Teh, L.W. Toward 21st Century Learning: An Analysis of Top Performing Asian Education Systems' Reforms. Asia-Pacific Education Researcher,23(4):779781. (2014)

[3] Nuri, \& Rusilowati, A. Pembelajaran Berbasis Produksi sebagai Upaya Peningkatan KeterampilanProduktifitas Siswa SMK. Physics Communication, 2(1), 46-51. (2018)

[4] Charalambidis, DIct in the Future Classrooms and Teaching: Preparing the knowledge workers of the 21st century. IFIP Advances in Information and Communication Technology, 437, 56-62. (2014)

[5] Wenno, I. H., Esomar, K., \& Sopacua, V. (n.d.). Analisis kesulitan belajar dan pencapaian hasil belajar melalui strategi pembelajaran Inkuiri. 378-385. . (2013)

[6] Sitepu, R. B., Rusilowati, A., Subali, B., \& Khafifi, A. S. Analysis of Vocational School StudentsAbility in Conceptual Understanding, Jurnal Ilmu Pendidikan Fisika (JIPF) 4(1), 28-32. (2019)

[7] Parry, K., Kirabo, E., \& Nakyato, G. Working with parents to promote children's literacy: a family literacy project in Uganda, 1-15. (2014)

[8] Saleh, B. 'Literasi Teknologi Informasi dan Komunikasi (TIK) masyarakat di kawasan Mamminasata', Jurnal Pekommas, 18(3), 151-160. (2015)

[9] Rustaman. Y. Nuryani. Procceding Seminar Nasional IPA III: Peningkatan Kompetensi Profesionalisme Guru Sains Berkelanjutan Melalui Penelitian dan Publikasi Ilmiah. Semarang UNNES FMIPA. ISBN: 978-602-99075-2-0. (2012)

[10] Levin, G. J. Teaching Generation TechX with the 4Cs: Using Technology to Integrate 21st Century Skills. Journal of Instructional Research, 1:5. (2012) 